[Original Article]

Received July 13, 2017

Revised October 21, 2017

Accepted October 27, 2017

${ }^{\dagger}$ Corresponding author

(yiyhee@hanyang.ac.kr)

ORCID

Yifang Wang

http://orcid.org/0000-0002-1962-3887

Jinkyung Lee

http://orcid.org/0000-0001-7643-513X

YOUN HEE LEE

http://orcid.org/0000-0002-2241-3899

This paper is a part of a master's thesis.

\section{Fashion design applying to the features of the Chinese Zhuang costume}

Yifang Wang, Jinkyung Lee and Younhee Lee ${ }^{\dagger}$

Dept. of Clothing \& Textiles, Hanyang University, Korea

\begin{abstract}
This study analyzes the characteristics of clothes worn by the Zhuang in order to produce new fashion designs, and to propose diverse new directions in fashion design. Research was conducted using a bibliographic survey on the cultural background, characteristics, and relevant techniques of the Zhuang costume and that of minority races in China. This study deploys four styles of design for women's wear. With the inspiration of the traditional Zhuang costume, black and blue were the colors mainly used for the Zhuang people and the material was mostly denim. Denim blends in well for the contemporary facilitation of the Zhuang costume, which is known for knitting technique, fur and hemp fabric as patchwork, and embroidery works. It is appropriate to express the joyful and happy mind of Zhuang people with extraordinary colors, exaggerated silhouettes, and various decorations. Images of nature, such as the sun, mountains, rivers, water, fish etc., expressed the nature worship of the Zhuang in contemporary design, representing the simple life and peaceful mind. This research develops a new fashion design and displays the possibility for diverse design development through new insight in contemporary fashion design.
\end{abstract}

Keywords: Chinese ethnic minorities(중국 소수민족), Zhuang costume(좡족 복식), Zhuang culture(좡족 문화)

\section{Introduction}

최근의 세계 유행 경향을 보면 동양적인 요소가 반영된 에스닉 룩이 강하게 대 두되고 있다. 특히 중국이 글로벌화 되면서 중국의 전통 복식 역시 세계 복식 트렌 드에 많은 영향을 미치고 있다. 중국은 한족과 55개 소수민족으로 이루어진 다민족 국가로, 중국 전역에 분포하고 있는 소수 민족은 크게 중국 남부에 자리하고 있는 소수민족과 북방에 살고 있는 소수민족으로 구분할 수 있다. 각 소수민족이 착용하 는 복식은 실루엣, 색채, 소재, 무늬, 장신구 등이 다양하며, 그 중에서도 소재는 방 직, 자수, 납염의 형식이 다양하고 정교하게 제작된다(Beijing Institute of Fashion 
Technology [BIFT], n.d.a). 소수민족의 문화는 예로 부터 전승된 전통이 있는 소중한 자산이다. 그러나 중국의 의복이 서양화, 현대화되면서 소수민족의 전 통복식 착용 역시 점차 감소하는 추세이다.

이러한 상황에서 최근에 중국 전통 소수민족 복식 에 관심이 많아지면서 소수민족 복식에 관한 연구가 많아지고 있다. 중국 소수민족 복식의 현대화에 관한 연구(Seo, 2015), 중국 소수민족 복식의 특징(Wu \& Lee, 2006)과 중국 소수민족 복식을 응용한 패션디자 인 연구(Li, 2014; Xie, 2013; Zhang \& Kim, 2011), 중국 소수민족의 전통 텍스타일에 관한 연구(Liu \& $\mathrm{Kim}, 2016)$ 등 중국 소수민족 복식의 연구가 다양하 게 이루어지고 있다. 이에 본 연구는 아직 연구가 미 흡한 좡족(壮族) 복식에 대하여 조사, 분석하고 이를 활용한 패션디자인을 전개하고자 한다.

좡족은 인구 1,800 만 여명으로 중국의 소수민족 중 가장 많은 인구를 차지하고 있는 민족이며, 소박하고 아름다운 복식 문화를 가지고 있다. 좡족은 역사가 오래되어 분포하는 지역도 광활하고 복잡하며, 이러 한 복잡한 지형을 기반으로 한 생활환경에서 아름답 고 다양한 스타일의 복식이 형성되었다. 민족의 생활 습관과 문화 특징을 잘 융합하고 있으며, 장식 공예 에 있어서도 정밀하여 중국 소수민족의 대표 민족복 식으로 공인되고 있다.

본 연구의 목적은 중국 소수민족 좡족의 문화적 배 경과 복식 문화를 조사하고, 좡족 복식의 특징을 분 석하여, 좡족 복식의 다채로운 특성을 바탕으로 새로 운 패션디자인을 전개, 제작하여 다양하고 창의적인 패션디자인의 방향을 제안하고자 한다. 이러한 연구 는 중국 소수민족 복식의 현대화를 위한 방법으로 의 의가 있을 것으로 기대한다.

연구 방법으로 중국 소수 민족의 문화와 복식 및 좡족의 복식에 대한 문헌 자료를 기반으로 좡족 복식 의 문화배경, 복식 특징에 관한 기법 등을 조사하였다. 문헌자료와 사진자료는 「미려적금수-좡족복식(美丽的 锦绣-壮族服饰)」, 「중국침직복식대전(中国针织服饰大 全)」,「중국민족복식문화도전(中国民族服饰文化图典)」, 「운남소수민족복식(云南少数民族服饰)」 등의 저서를 통 하여 주로 조사 분석하고, 북경복장학원민족복식박물관 (北京服装学院民族服饰博物馆, www.biftmuseum.com), 광서박물관(广西博物馆, www.gxmuseum.cn), 광명일보
(光明日报, epaper.gmw.cn) 등의 웹사이트를 통하여 조 사하였다. 이러한 선행연구 분석을 통하여 좡족 복식 에 관한 특성을 고찰한다. 이러한 내용을 바탕으로 좡족 복식의 특성을 활용한 여성복 디자인 4점을 제 안하였다.

\section{Background}

\section{The cultural background of Zhuang}

\section{1) The distribution of Zhuang people}

좡족(壮族)은 농업이 생활의 중심으로 벼농사에 능 하고, 역사가 오래되었다. 좡족은 중국과 베트남에 걸 쳐 거주하고 있는 민족이다. 중국의 소수민족으로서 의 좡족은 인구가 1,600 만여 명으로 가장 많다. 좡족 은 지리적으로 기이하고 특이한 지형 또는 산수가 수 려하고 자연풍경이 매우 아름다우며, 기후가 온화하고 강수량이 충분해 열대작물이 잘 자라는 곳에 분포, 거 주하는 경향을 보인다. 광서좡족자치구(廣西壯族自治 區)는 중국 내 좡족의 최대 거주지로 전체 좡족 중 약 $87 \%$ 인 $14,207,143$ 명이 거주한다(National Bureau of Statistics of China, 2004)(Fig. 1).

좡족은 시대의 흐름에 따라 진(秦) 서구(西甌), 락월 (駱越) 등으로 불리다가 송대(宋代)에는 당(撞), 동(僮), 중(仲)으로, 명 - 청대에는 동인(僮人), 양인(良人), 토 인(土人) 등으로 호칭되었다. 신중국 성립 후 동족(僮 族)으로 통일되었다가, 동(僮)이 차별적인 의미를 갖고 있다 하여 1965년에 좡(壯)으로 개칭되었다. 이들은 고 대부터 원주민족인 백월(百越)의 일종으로, 진 · 한대 (秦汉代)부터 중화 왕조의 지배하에 간접통치를 받아 왔으며, 명 - 청대에 이르러서는 주현제(州县制)에 의 한 직접통치로 개편되는 정책이 추진되어 좡족을 비 롯한 소수민족의 반발을 사게 되어 빈번한 반란이 일 어나게 되는 요인이 되었다. 좡족은 역사적으로 자신 들에게 일어난 이러한 불합리한 상황을 1850 년의 태 평천국(太平天国)의 난이나 1929년 발발한 우강혁명(右 江革命)에 참가하는 등의 방식으로 타개하고자 한 혁명 적 성향과 전통을 지니고 있는 민족이다(Hwangmaehee, 2010).

1952년 광서 서쪽에 계서동족자치구가 설립된 이래 1956년에는 자치주로 개편되었다가 1958년에 광서 


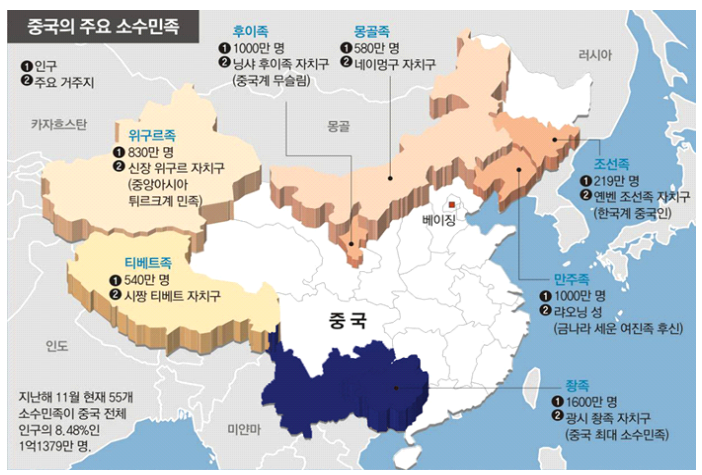

<Fig. 1> The distribution map of Chinese ethnic minorities

From. Lee. (2011). http://news.donga.com

전역으로 확대되어 광서동족자치구가 되었으며, 현재의 광서 좡족자치구(广西壮族自治区)가 구성되었다. 인구 는 자치구의 중심지인 난닝(南宁)과 류저우(柳州)에 약 600 만여 명이 거주하고 있는 것으로 파악되며, 1958년 과 1962년 윈난성(云南省)과 광둥성(广东省)에 각각 원산 좡족 먀오족자치주(文山壮族苗族自治州, 문산 좡 족 묘족 자치주)와 롄산 좡족 야오족 자치현(连山壮族 瑶族自治县, 연산 좡족 요족 자치현)이 설립되었다 $(\mathrm{Li}$, 2012).

\section{2) The life style of Zhuang}

중국은 다민족 국가이면서 다종교 국가이다. 좡족은 원시적인 종교 형태인 자연 숭배를 거쳐 당·송대(唐· 宋代) 도교와 불교가 전파되었고, 근대에 와서는 기독 교와 천주교가 전파되면서 종교적 다양성을 갖추기 시작하였다. 좡족은 특정 종교에 대한 억압과 같은 문 화적 퇴폐성이 적기 때문에 동서양의 종교와 자연숭 배사상을 복합적으로 수용하였는데, 이는 사람들의 생 활에 어느 정도 영향을 미쳐 복식은 검정색을 즐겨 사 용하고, 자연을 상징하는 동 - 식물 문양을 사용하는 등의 특징이 나타난다( Wu \& Lee, 2006).

좡족의 복장은 검정을 주요 색상으로 한다. 좡족의 검정에 대한 사랑은 좡족 선민들의 개구리와 업구렁 이, 청개구리와 같은 동물숭배로부터 전해 내려왔다. 광서 닝밍, 룽조 화산의 절벽에 그려져 있는 의인화 된 개구리의 모습으로부터 고대 좡족 선민들의 숭배 의 흔적을 볼 수 있다. 오늘까지 텐어, 동란 홍수 강 변의 좡족은 매년 정월 초하루부터 2 월 2 일까지 성대
한 “마와이(개구리)제”를 진행한다(Fig. 2). 비와 밀접 한 관계를 갖고 있는 마와이를 천둥신의 딸(인류와 동물, 식물들의 번식을 도와주는 여신)로 여기고, 무 릎을 꼻고 모시는 것이다. 마와이 춤은 마와이의 출생, 밭갈이 춤, 모내기 춤, 잡초 뽑는 춤, 고기잡이 춤, 방 직 작업 춤, 수확을 경축하는 춤 등이 포함되어 있다. 이는 좡족 사람들이 전통적으로 남자는 농작물 생산 의 전반 과정과 밭일을 도맡아 하고 여자는 방직을 하는 전원생활의 정서를 표현하였다. 무용의 전체 과 정에서 여성의 가면을 쓰고, 여성의 복장을 하고 있 으며, 큰 북을 두드리는 출연자는 지휘자이자 신성한 마와 이의 화신이다 $(\mathrm{Li}, 2012)$.

좡족은 일찍이 농업이 발달하여 삼칠삼, 도마뱀붙이, 회향유, 감자류가 유명할 뿐만 아니라, 사탕수수 생산 량이 전국에서 수위를 차지하는 농업도시이다. 이들의 주식은 쌀이며, 부식으로 옥수수나 고구마 및 여러 잡 곡 따위를 섭취한다. 또한 절인 고기 내지는 시큼하고 단 음식, 차와 음료 등을 즐긴다. 명절에는 홍란초(紅 欄草), 삼월화(三月花), 밀몽화(密夢花), 단충 잎 등, 식 용식물들을 이용하여 찹쌀에 흑색, 홍색, 황색, 자색, 백색의 여러 가지 색깔로 물을 들인 후 쪄낸 오색 밥 을 즐겨먹는데, 색, 향, 맛이 독특할 뿐만 아니라 이를 먹음으로써 농사가 풍작의 해가 되고, 오곡이 풍성해 지길 기원하는 의미가 있다(Yang, 2005).

좡족은 가무를 좋아하고 공예품으로 오색의 실로 아름답게 자수를 입힌 좡 비단(壮錦)이 유명하며, 전통 복식은 남녀 모두 흑색을 사용한다(Hwangmaehee, 2010). 예로부터 초문화의 영향을 받아왔는데, 습하고 산이 많고 물이 많은 환경에 의해 이들은 짧은 상의와 긴 치마를 입는 복식형태가 발달하였다. 짧은 상의는 시 원하고 바람이 잘 통하고 걸어 다니기가 편리하며 강 을 건너다니고 일과 생활을 하는데 편리하다. 또한 높 고 추운 산악지대에 거주하는 좡족은 짧은 상의에 긴 주름치마를 입는데, 그 주름은 층이 많고 묵직하고 밑으로 처져 있어 바람이 잘 새지 않는 보온 작용을 한다. 또한 추위를 견딜 수 있고 상처를 입지 않게 막 아주는 역할을 할 수 있는 보파(包帕)도 발달하였다.

좡족 여성은 가시넝쿨과 뱀, 벌레 등 해충을 피하기 위하여 긴 치마에 종아리 부위에 행전(行㿈)을 치는 형태의 복식을 착용하고, 짧은 치마를 입었을 때에는 세련되고 깔끔한 면을 보여준다. 앞치마는 상하의의 


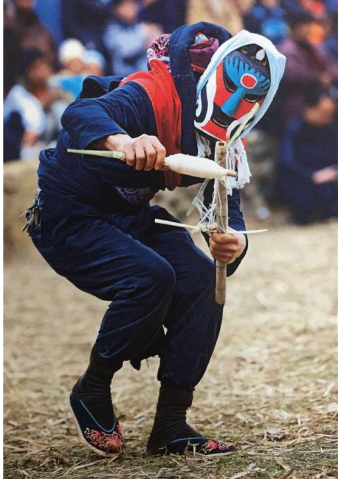

<Fig. 2> Directing the daughter of Thunder God to delight

From. Li. (2012). p. 167.

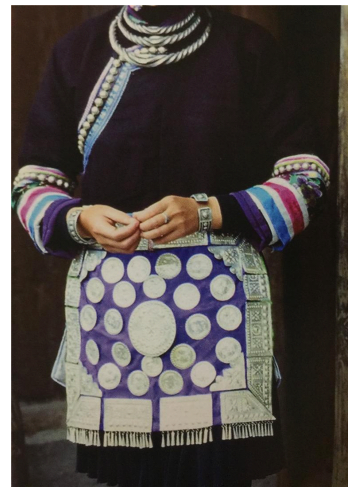

<Fig. 3> Zhuang apron From. Li.

(2012).

p. 208.
연결 부분에 두르는 띠이다(Fig. 3). 이는 여성의 육체 미를 꾸며주는 작용을 할 뿐만 아니라, 중요한 실용 성도 가지고 있다. 벼농사의 작업적 특성상 허리를 오랜 시간 굽힌 상태로 일을 해야 하는데 이는 허리 에 많은 부하를 주어 큰 무리가 가게 될 뿐만 아니라 바람의 침습을 자주 당하게 된다. 앞치마는 이러한 취 약점을 보안하기 위하여 보온성을 가지면서 허리의 부 담도 덜어 주는 역할을 한다(Guangxi Zhuang Autonomous Region Museum, n.d.).

\section{The characteristics of Zhuang costume}

\section{1) Silhouette}

좡족 복식의 전반적인 실루엣은 직선적인 형태의 상의에 치마 혹은 바지를 착용하고 성별별로 복식 스 타일이 차이가 있다. 좡족의 복식은 형태에 따라서 짧 은 양식과 긴 양식의 실루엣으로 나누어지는데, 긴 양 식은 복식의 길이가 무릎까지 내려오며, 좡족 여자들 이 꽃문양이 있는 옷과 짧은 치마, 바지를 입으면서 허리띠나 앞치마를 착용하는 형태이다. 일상생활에서 는 짧은 상의에 무릎까지 내려오는 장삼을 입고 넓은 바지를 입는데, 이를 통해 좡족이 평소에는 장식에 신 경 쓰지 않고 간단하고 소박하면서 자연스럽게 입는 것을 좋아한다는 사실을 알 수 있다. 명절에는 매듭 을 묶어 “凸” 모양을 나타내는데 앞치마(满襟围裙)와 은장식, 자수문양이 화려한 쓰개를 많이 입는다.

〈Fig. 4〉의 복식은 결혼식에 여자가 입는 옷이다.
스탠드칼라와 옷소매는 문양으로 장식된 자수가 있 고 허리는 타이트한 형태이며, 반원형 아래 옷자락이 왼쪽으로 향하는 모습을 띠고 있다. 마치 새 날개와 같이 생긴 형태는 좡족 언어로 "비디란(必迪兰)"이라 불리며 이는 매의 날개라는 뜻을 갖고 있다. 평투(平 头)지역에서 여성 명절 복식은 상의길이는 다소 짧은 형태이고 소매는 손목까지 오는 형태이다. 소매 끝부 분은 붉은색 천을 붙였고, 가슴의 앞뒤로는 사각형에 자수를 놓은 천을 붙여 화려함을 주었다. 하의는 치 마형태에 바지로 폭은 넓고 밑의 부분에 발이 나오도 록 되어 있다(Fig. 5). 머리에는 천으로 두건을 만들고 두건의 끝부분을 길게 빼내어 포인트를 주었다. 또는 은포(银泡)로 만든 복식도 입는다. 부분도 은장식을 끼고 우측에서 발까지 내린 자수 요대를 착용한다.

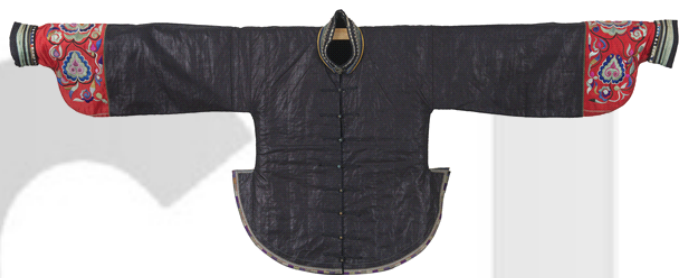

<Fig. 4> Yunnan Xicheng Zhuang black embroidery female wedding dress (云南西畴壮族黑色刺绣女嫁衣) From. BIFT. (n.d.b). http://www.biftmuseum.com

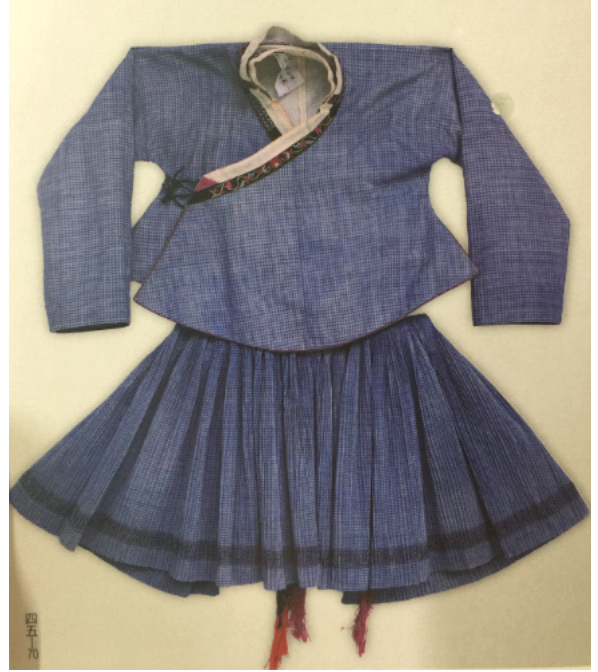

<Fig. 5> Shaxi Zhuang women dress (沙梨壮族妇女服饰)

From. Yang. (2005). p. 198. 


\section{2) Color}

좡족 복식의 색채는 주로 파랑, 검정, 흰색으로 나 타난다. 여기에 광택이 있는 주홍색이나 진홍색, 도홍 색, 등황색, 녹색, 소라색 등 색상의 실로 자수 도안을 짜서 바탕 색깔과 선명한 대조를 이룬다는 특징이 있 다. 좡족 복식은 여자들이 직접 방직해서 만들고 염 색한다. 색채에 따라 ‘흑의좡', '남의좡’과 '백의좡'으 로 나누어진다. 근대에 접어든 이후부터는 인디고(蓝 靛)를 주 염료로 사용하며 검정과 파랑색 계열을 위 주로 염색한다. 검정은 좡족 패션에 있어서 항상 선 호되는 색상으로 좡족 복식의 가장 많이 사용되는 색 상이다. 이러한 좡족 복식의 색채는 그들의 주생활 형태인 농경생활과 잘 어울리며, 청산녹수가 많은 생 활환경과도 잘 어울린다( $\mathrm{Yu}, 2012)$.

"흑의좡(黑衣壮)" 복식은 검정색을 바탕으로 한 복 식으로 오늘까지 가장 전통적이면서 특색 있는 좡족 복식이다. 좡족은 검정색을 사용하여 민족의 표시를 뚜렷하게 드러내며, 장식에 있어서 실용적이고 소박 하면서도 아름다운 면모를 보여준다(Fig. 6). 남의좡 은 손으로 짜고 염색한 남색 원단을 입는다. 이들은 남색 계열 색상을 애호해서 남의좡이라고 불린다. 남 의좡은 상의와 바지를 세트로 많이 입으며, 주로 우 아한 이미지가 부각된다. 여자들이 앞치마를 차림을 많이 하고 모자도 다양한 은으로 장식해서 입체적인 질감을 표현하였다(Fig. 7). 백의좡은 흰색 상의를 애 호하는 경향이 있어 백의좡으로 불린다(Fig. 8). 흰색
복식 안에 라운드 형태의 상의를 착용하고 하의는 주 로 검정색 계열의 바지를 착용한다("Black costume of Zhuang", 2015; "Costume of Zhuang", 2014). 좡족 들은 검정색이 부귀와 기쁨을 상징한다고 여기는데, 이를 이유로 평소에는 연한 색을 많이 입지만 명절에 는 진한 색상과 검정 색상의 옷을 많이 입는 편이다.

\section{3) Fabric and textile design}

좡족은 농경민족으로 복식 소재를 주로 스스로 재 배한 면, 마, 견을 주로 사용하며, 때로는 견을 사용하 기도 한다. 좡족의 여러 복식 형태 중에서도 귀주성 좡족 복식이 가장 대표적이며, 귀주성의 좡족 복식은 수직기로 매우 정교하게 만들어져 예술품이라고 할 수 있을 정도로 훌륭한 외양과 품질을 자랑한다. 노동할 때 착용하는 좡족들의 복식은 검소하고 우아하다 (Yang, 2005).

좡족은 예로부터 마를 잘 짜기로 유명하였는데 한 나라 때 이미 우질 련자천(練子布)을 생산했다. 좡족 은 그들의 선민 세대부터 본지의 다양한 식물 섬유를 이용하여 남방의 무더운 기후에 맞는 방직품을 짜내 는 일류 기술을 보유해왔다. 면화는 해외에서 도입되 었다. 동진시기에 이르러서 목화는 운남, 광서의 좡족 지구에서 재배되고 있었으며, 면 짜기 방법이 도입되 면서 널리 보급된 당대(唐代)에 이르러서는 이미 상 당한 규모를 형성한 상황이었다.

광서는 송나라 시기부터 뽕나무를 심고 누에를 키

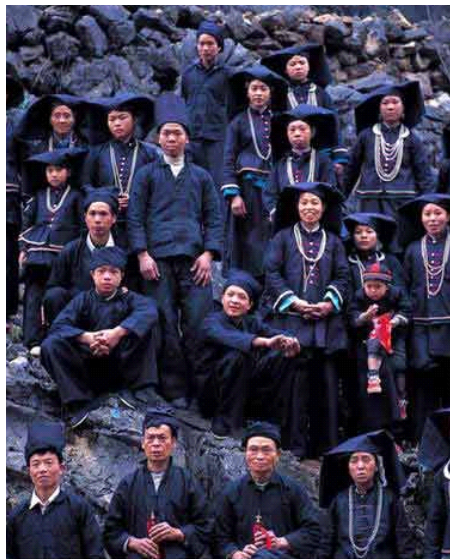

<Fig. 6> Black costume of Zhuang From. Sammirabbit. (2010). http://www.rayli.com.cn

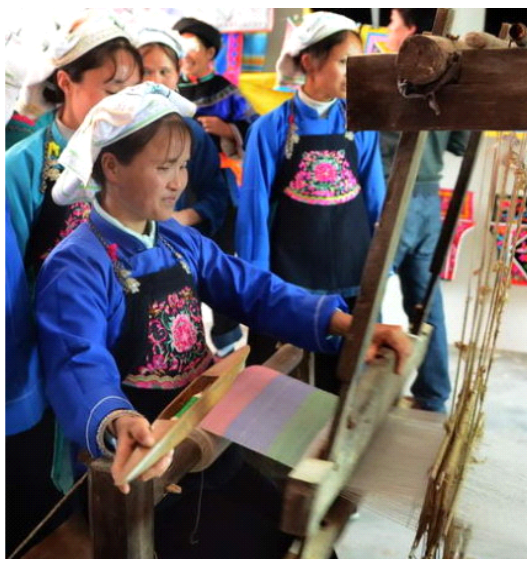

<Fig. 7> Indigo costume of Zhuang From. Yang. (2005). p. 207.

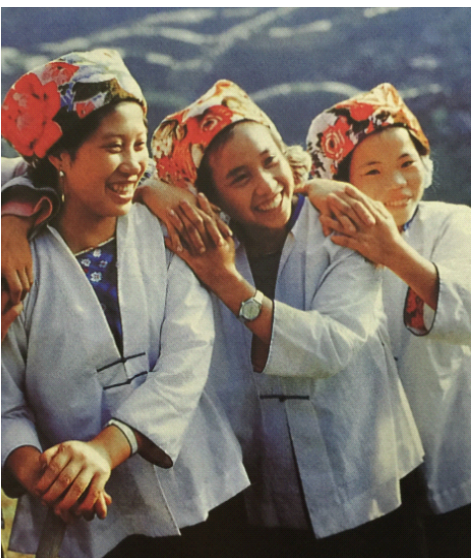

<Fig. 8> White costume of Zhuang From. Yang. (2005). p. 209. 
워 비단을 짰다. 송나라 시기 좡족 지구의 각종 견직 물들은 모두 차갑고 수수한 색상 위주였는데, 이러한 듬직하고 간단한 풍격은 후에 좡족 복식의 특징 형성 에 지대한 영향을 주었다. 방직에 종사하는 좡족 여 성들은 한족의 비단 짜기 기술을 흡수하면서 자신의 비단 짜는 방식을 융합하여 민족의 생활 습성과 문화 특징이 조화된 좡족 특유의 장단을 짜냈다. 사면 혼 직은 좡 비단의 제일 큰 특징으로 면의 따스함과 두 터움을 가지고 있을 뿐만 아니라, 사의 화사함을 구 비했다. 오랜 발전 과정을 거치면서 장단은 단색으로 부터 오색찬란하게 변화해 왔다. 좡 비단은 주로 민 간 좡족 부녀들이 짜는데, 자방한 세 백면 사선을 경 선으로 하고 꼬지 않은 채색 있는 선을 위선으로 하 여 서로 견직하여 얻은 것이다.

좡족 복식 소재의 표현 방법은 대체로 염색, 방직, 자수의 세 방법으로 구분할 수 있다. 특히 여성복식 은 이 세 가지 기법을 적절히 활용하고 은장식을 가 미하여 좡족 복식의 우아한 아름다움을 표현한다. 이 와 같은 좡족 복식의 특징을 통하여 그들이 생활환경 과 조화되어 만들어낸 천년역사의 지혜와 정서를 탐 구할 수 있다.

\section{(1) Dyeing}

염색 기법 중 날염(印染)은 실이나 직물, 특히 직물 에 부분적으로 물감을 발라 물들여 필요한 무늬가 나 타나도록 하는 기술이다(“Textile printing", n.d.). 좡 족의 날염법은 제작 방식에 따라 '찰염(扎染)', '납염 (蜡染)', ‘협염(夹染)'의 세 가지 방법으로 구분된다. 찰염(扎染)은 원단에 매듭을 짓고 염색하는 것이다. 납염(蜡染)은 수공초로 원단에 그림을 그리고 염색하 는 것이다. 협염(夹染)은 타이다이(tie-dyed)로 부르며 문양을 조각하는 나무집게로 염색하는 것으로 날염 의 전신이다. 그 중에는 좡족은 찰염(扎染)과 납염(蜡 染)을 많이 사용한다.

납염은 산에서 채취할 수 있는 람초라고 불리는 식 물을 많이 쓴다. 좡족의 전통원단은 색깔을 잘 흡수 하는 편이고, 인디고 염색 이후는 남색과 흰색이 분 명하게 보인다는 특징이 있다. 짧은 선과 작은 점으 로 순서가 명확한 식물무늬, 동물무늬 그리고 기하학 무늬를 조합한다 $(\mathrm{Li}, 2012)$. 천을 염색한 후 우각풀로 바르고 접는 과정을 반복하면서 색상이 점차 밝아진

다(“Costume of Zhuang”, 2014).

찰염은 현대에 접어들면서 여성복에서 광범위하게 적용되고 있다. 타이다이 기법의 경우에는 20 세기에 접어들면서 한족지역에서는 점차 사라지고 있는 추 세이지만, 광서 지역에서는 타이다이를 쉽게 제작할 수 있기 때문에 좡족 여성들에 의해 해당 공예 기법 이 전승되어 왔다. 염색하기 전에 접기, 말기, 쥐기 등 의 작업 방법을 거쳐서 원하는 형태를 잡은 뒤 바느 질로 고정해서 염료에 담그는 방식으로 제작된다. 이 러한 제작 방식을 거쳐서 염색된 천은 마른 후에 바 느질을 풀었을 시 자연스러운 그러데이션 패턴을 형 성하게 된다(Fig. 9, Fig. 10). 좡족의 찰염 무늬는 체 크 꽃이나 매화, 만자, 새 형상의 문양 등 다양한 요 소에서 영감을 받아 디자인되어 창의적 표현이 무한 하다는 특성을 지니고 있다( $\mathrm{Li}, 2012)$.

납염은 염색의 여러 기법 중 하나로 방염(防染)의 일종이며, 밀랍이 응축되는 특성을 이용하는 염색 방 법이다. 대략적인 방법은 염색 시에 염료가 침투하는 것을 막아야 하는 부분을 밀랍으로 덮고 염색을 한다. 기록에 따르면 중국에서의 납염은 한대(漢代)에 운난 (雲南)에서 시작된 것으로 확인되고 있다. 납염은 직 물처리, 밑그림 그리기, 도안그리기, 염색, 밀랍 제거의 5 가지의 공정절차를 거쳐 완성된다. 직물처리 과정에 서는 정련과 표백 등을 실시하며, 도안은 밀납액으로 그린다(Fig. 11). 전통적인 납염용 칼을 사용하여 밀 랍을 잘라 납염용 짠찡(tjanting)을 사용한 액체 상태의 밀랍으로 면이나 면마 혼방을 주로 사용하며, 견직물

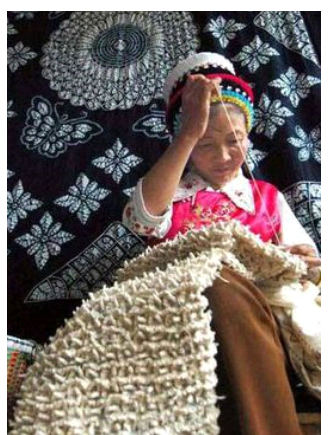

<Fig. 9> Tie-dyed From. China.com. (2006).

http://www.china.com.cn

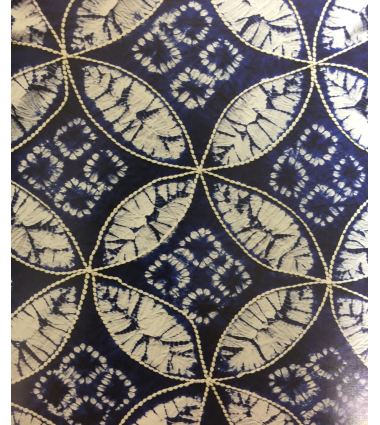

$<$ Fig. 10> Guangxi Zhuang tie-dyed fabric owned by Tae Museum From. Photographed by the author. (2016) 


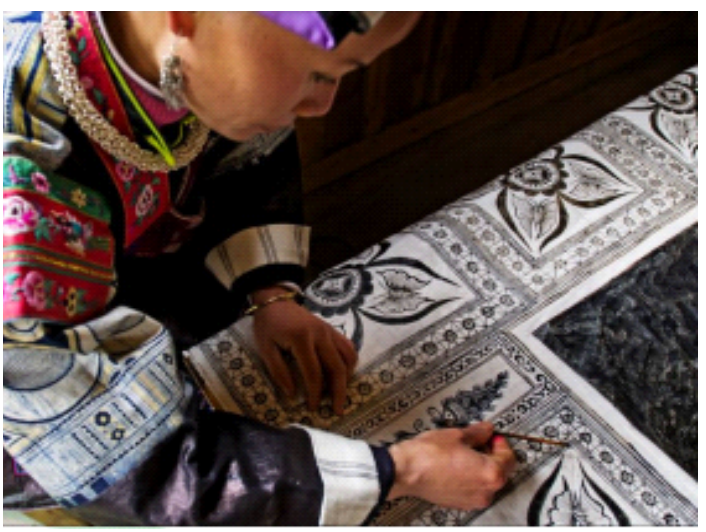

<Fig. 11> Wax printing

From. Zhangjiajie. (2014). http://www.zhangjiajietourism.com

등에 도안을 그리기도 한다. 이 짠찡은 밀랍이 좁고 긴 관에서 나오는 다른 나라에서 사용되는 것과는 달 리 여러 겹의 동판을 거쳐 양쪽 끝으로 액체상태의 밀랍이 나오는 역삼각형의 형태를 갖추고 있다(Liu, \& Kim, 2016).

\section{(2) Embroidery}

자수는 좡족 복식에 광범위하게 응용되고 종류가 다양하다. 민속 특색도 강하게 가지고 있다. 주로 마, 비단에 실크, 면실 등으로 꽃무늬를 새긴다. 자수가 유행하기 전에는 좡족 선민들 사이에 오랜 동안 문신 이 유행했다. 원시사회 말기 좡족 선민들이 핀으로 자기 시족의 토템(뱀, 개구리, 새, 물고기, 태양 등) 무 늬를 신체에 새겨 시족 부락을 표시하여 다른 부락과 구분하였다.

좡족 청년 남녀들이 사랑을 표현하는 대표 품목인 수구(绣球)는 자수가 놓인 둥근 구(球) 모양의 비단 방 울을 일컬으며 가장 창의적인 좡족의 자수가 사용된다. 송나라시기에 등장하여 여러 자수들 중 가장 먼저 장 식에 사용된 자수이다. 수구(绣球)는 감귤의 구조를 모 방하여 겉면으로는 12 조각의 꽃잎으로 구성되었고, 위 는 봉황, 원앙, 백학, 목단, 연꽃 등 꽃과 새의 도안으 로 장식하여 사랑이 일 년간 꽃처럼 사시장철 활짝 피였음을 상징한다(Fig. 12). 또한 구(球)의 내부에는 낱알, 목화씨, 건조시킨 콩 등의 물건을 넣어 마음속 의 사랑의 씨앗이 꼭 싹이 트고 꽃이 피며 열매를 맺 었음을 상징하였다.

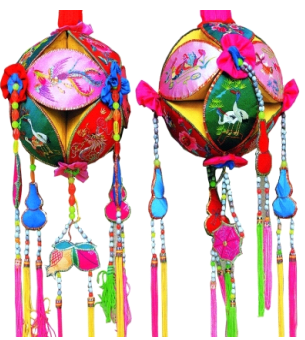

<Fig. 12> Zhuang silk embroidery ball(绣球) From. Yu. (2012). http://epaper.gmw.cn

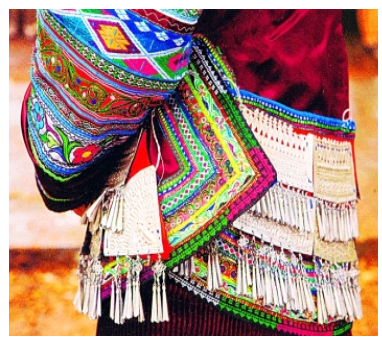
embroidery

From. Yu. (2012).

http://epaper.gmw.cn
<Fig. 13> Zhuang

청나라시기에 자수와 면직법은 이미 보편적으로 좡 족 복식의 중요 부위에 응용되었고, 소박하고 우아한 풍격을 드러내어 화려한 모습을 보였다 $(\mathrm{Li}, 2012)$. 좡 족 복식의 이러한 변화는 전 중국 복식의 환경 변화 와 밀접하게 관련되어 있다. 자수의 침법은 양한 시 기이후로 변수에 국한되어 있었으나, 당나라시기에 평수로 변화되면서 점차 발전되기 시작하다가, 송나 라시기에 들어서 자수는 서법과 그림을 모방할 수 있 었을 뿐만 아니라 라인과 색채의 표현력도 날로 풍부 해 지게 되었다(Fig. 13).

\section{4) Pattern}

좡족은 그들의 일상생활에서 접할 수 있는 유형이 나 종교나 신화와 같은 소재를 문양에 주로 사용하여 기하학적 무늬, 동물무늬, 식물무늬와 같은 문양으로 표현하였다. 일상생활과 관련된 무늬는 주로 다양한 종류의 동물 또는 식물을 비롯하여 산이나 강, 나무, 태양, 달과 같은 자연환경에서 영감을 얻어 이를 문 양화하였다(Fig. 14).

좡족은 이와 같이 구체적으로 묘사되는 이미지 이외 에도 추상적인 형태의 무늬도 사용하는데, 좡족의 생 활에 문화적으로 자연환경과 종교와 같은 요소들이 영향을 주었고, 이들의 정신세계는 세상만물의 이치 나 인생의 깨달음과 같은 것들을 무늬화하여 폭넓게 표현한 것이다. 이들이 도안을 구상할 때에는 묘족자 수와 같은 기하학 형태로 큰 틀을 잡아놓은 다음, 각 틀 안에 다양한 구체적인 내용의 수를 놓거나 틀의 형 태에 맞추어 재단된 무늬 천을 놓고 그 위에 수를 놓 는 등의 방법으로 표현된다. 이러한 방식은 기하학적 문양에 王무늬, 루무늬, 십자무늬와 같은 무늬가 함께 

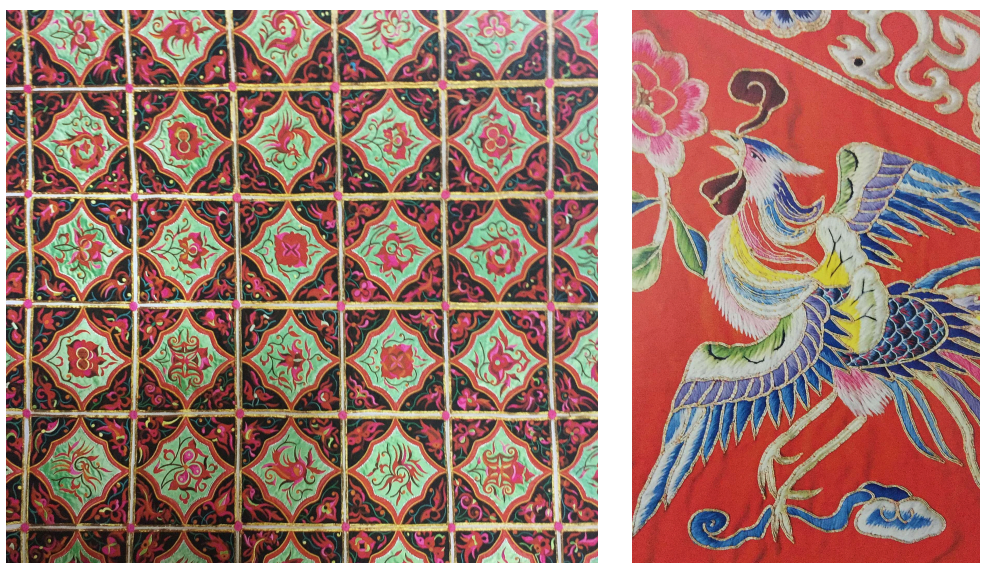

<Fig. 14> Zhuang embroidery: plant \& animal pattern owned by Relay Museum

From. Photographed by the author. (2016)

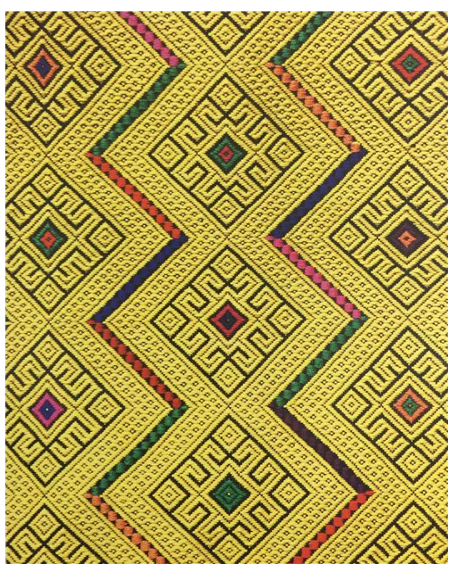

$<$ Fig. 15> Geometric pattern of Zhuang

From. Li. (2012). p. 207.

표현되는 문양을 통해 볼 수 있다(Fig. 15)(BIFT, n.d.a). 동물무늬는 사자, 용, 코끼리, 닭, 봉황, 물고기, 참새, 원앙새, 두루미 등이 사용되고 식물무늬는 국화, 풀, 석류, 복송아 꽃, 불수감나무 등이 주로 활용된다.

\section{5) Accessories}

현대 사회에서의 장신구의 착용은 주로 몸치장을 목적으로 하지만, 초기의 장신구 착용의 목적은 주술 적인 의미나 신분의 구별과 같은 목적이 강했으며, 점 차 개인의 미적 본능을 표현하기 위한 목적으로의 장 신구 착용 목적이 변하였다. 좡족의 장신구는 복식을 보다 아름답고 단정하게 만들어준다. 중국은 인류 문 명의 발상지로 여겨지는 역사가 유구한 문명국으로, 이들 역시 수천 년간 각 민족별로 특색 있는 장신구 를 만들어 착용해왔다. 이러한 중국인들의 장대한 역 사를 반증하듯이 장신구의 착용은 구석기 말부터 그 원형이 이미 나타나는 등 상당히 오래전부터 이용되 어 왔다.

좡족의 장신구는 종류가 많다. 모자, 머리장식, 목 걸이, 귀걸이, 팔찌, 신발, 벨트 등이 있으며, 좡족 여 성들은 머리에 검은 두건을 쓰고 은장식을 많이 착용 한다(Fig. 16). 좡족은 머리 장식을 좋아하는 데 보파 (包帕)라고 부르며 다양한 모양을 가지고 있다. 보파는 휘감은 형태와 퍼지는 형태, 두 개가 연결된 형태도 있다. 보파의 높낮이, 색상과 무늬에 따라 서로 다른 지파를 표시한다. 좡족의 각 지파에 따라 대나무 갓
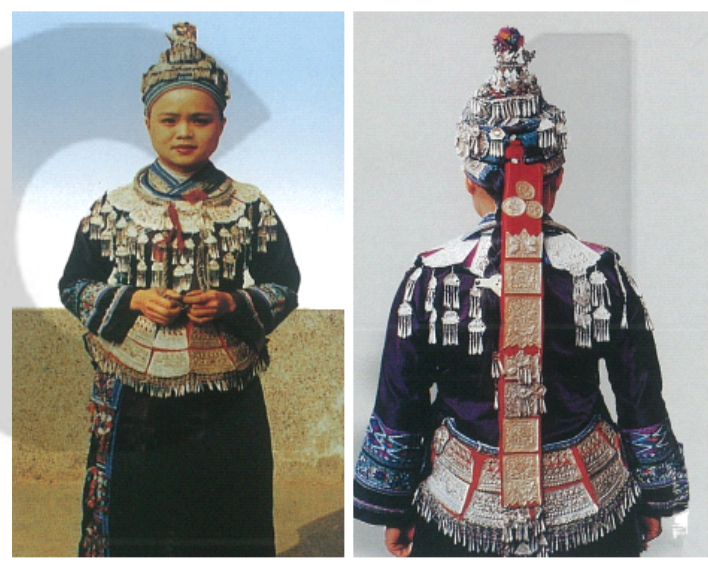

<Fig. 16> Fashion accessories of Zhuang From. Yang. (2005). p. 228.

을 쓰는 방법도 서로 다르다. 좡족의 보파는 실용적 이면서도 아름답고 특이한 머리 장신구로 색다른 모 습을 보여준다.

좡족의 여성들에게 앞치마도 특별한 장식구이다. 앞치마는 허리와 복부에 두르는 것과 치마 길이와 비 슷한 것, 상단을 목에 걸고 허리에서 묶는 디자인이 있다. 앞치마가 특별한 이유는 정성들여 수를 놓기 때문에 걸쳐있는 착용하는 장신구 중에서 가장 밝고 아름답다.

\section{Development of Design}




\section{Design concept}

본 연구에서는 중국 소수민족 복식의 현대화를 위 한 방향으로 좡족의 민족 복식의 특징을 응용한 패션 디자인을 제작하였다. 이론적 배경으로 문헌연구와 선행연구의 고찰을 통하여 좡족 복식에 대한 디자인 특성을 조사하고, 그 특성을 현대적인 패션 디자인에 연계하여 명절에 입는 예복(艺服) 2착장과 일상복 2 착장의 4착장 패션디자인을 전개, 개발하고 실물 제 작을 하였다. 작품의 주제는 좡족 복식의 예복(艺服) 를 기반으로 명절에 즐겁고 유쾌한 마음을 표현하는 'Happy Land'와 일상적인 좡족의 소박하고 부지런한 모습을 보여주고자 하는 'Peace of Mind'로 하였다.

실루엣은 좡족 복식의 직선을 기본으로 디자인하 였다. 짧은 상의와 바지 세트, 짧은 상의와 긴 주름 스 커트, 긴 원피스와 앞치마 등, 직선 실루엣의 아이템 으로 디자인하였다. Happy Land는 좡족 복식의 직선 실루엣에 기초하여, 좡족 명절의 소박하면서도 행복 한 모습을 대변할 수 있도록 표현하였다. Peace of Mind의 디자인도 직선 실루엣이며, 좡족 여성들의 부 지런한 일상 이미지를 표현하고자 장족 여성들이 착 용하는 긴 셔츠, 치마, 바지, 허리띠와 앞치마를 함께 착용하는 특징을 활용하여 디자인하였다.

색상은 좡족 복식에 많이 나타나는 검정, 파랑, 흰 색 등의 색상을 이용하여 좡족 복식의 문화를 표현하 였다. 명절에 착용하는 디자인과 일상복식의 2 가지 주제로 나누어 명절용 디자인은 원색을 많이 활용해 서 명확하고 화려한 분위기를 표현하고자 하였으며, 일상 착용 디자인은 파랑색과 흰색을 주로 활용해서 소박하면서도 자연스러운 복식의 특징을 담아 좡족 여성들의 평화로운 마음과 행복한 생활 모습을 표현 하였다. 또한 파랑, 빨강, 흰색, 노랑 등의 원색들과 조화될 수 있도록 디자인에 활용하였다.

소재는 일상생활에서 많이 착용하는 데님 원단과 니트를 주 소재로 활용하였다. 좡족 복식에 나타나는 검정색과 파란색의 자연 친화적 소재들은 데님의 느 낌과 잘 어울리는 소재에 착안하였다. 실용적인 데님 소재는 자유와 젊음을 상징하며 청년문화를 대변하 며, 본 연구에서도 데님의 이러한 특성과 의미를 활용 하여 자유로운 개념의 디자인으로 표현하고자 하였 다. 니트 소재는 여러 소재의 아이템들과 코디네이션 적 요소가 강하여 자연스럽게 혼합되고 장식될 수 있
어서 창의적인 표현에 활용하기 좋은 소재이다. 직물, 가죽, 모피 등과 같은 다양한 소재와 혼합하거나, 니 트에 여러 장식과 트리밍을 더하는 등 다양하게 응용 하여 차별화된 소재로 표현할 수 있다는 점에 착안하 였다. 다음으로 자수 기법과 패치워크 기법, 위빙 기법 을 활용하여 좡족 복식의 특징을 표현하고자 하였다. 좡족은 자연숭배 문화로 산, 태양, 동물, 식물 등으로 자수, 직조를 많이 한다. 본 연구의 작품의 문양도 주 로 좡족 사람들의 생활 주변에 자주 보이는 유형이나 현대 생활을 표현할 수 있는 이미지를 활용하였다.

장신구로는 모자, 신발, 귀걸이 등을 제작하였다. 좡족 복식에 활용하는 패치워크와 위빙기법, 펠트기 법을 많이 활용하였으며, 니팅도 더하였다. 이러한 과 정의 디자인 일러스트레이션은〈Table 1)과 같다.

\section{Design development}

본 연구 작품의 구체적인 디자인 전개는 다음과 같 다. 작품 1 은 좡족 여성들의 대표적 복식 차림인 짧은 상의와 넓은 통의 바지를 아이템으로 디자인하여 박 시하고 과장된 느낌을 표현하였다. 좡족 복식의 직선 실루엣을 기초로 디자인하고, 검정, 파랑, 빨강 등의 색상을 이용하여 현대 패션에 자주 활용되는 데님을 모던한 모습으로 디자인하였다. 컴퓨터의 출연을 대표 하는 게임 중 하나인 지뢰 찾기에서 영감을 얻어 패 턴 디자인으로 응용하였으며, 니팅과 패치워크 기법 을 활용하였다.

작품 2 는 검정 데님 원단을 사용하여 여성스러운 타이트 재킷을 제작하였다. 타이트 실루엣은 깔끔하 지만 창의적인 마직 원단의 조끼를 함께 연출하여 재 미있게 나타내고자 하였다. 좡족은 자연숭배 사상을 깊게 내포하고 있는 민족이라는 점을 고려하여 자연 친화적 소재를 선택하였다. 소박한 느낌의 데님 소재 를 바탕으로 모피와 니트로 부가적인 장식을 시도하 여 좡족 여성들이 명절날에 행복하고 기쁜 마음을 대 변할 수 있도록 표현하였다. 니트 조직은 핸드니팅으로 배색하여 대바늘뜨기와 코바늘뜨기로 활력이 넘치는 명절의 느낌을 강하게 표현하였다. 보파(包帕)를 좋 아하는 좡족 복식의 표현으로 겉면에 모피를 붙이고 구슬과 술로 장식하여 좡족의 민속적 느낌을 강하게 표현하고자 하였다. 상의는 슬림 치파오의 실루엣에 영감을 받고 차이니스 컬러로 디자인하였다. 긴 소매 
$<$ Table 1> Design illustration

\begin{tabular}{c|c|c|c|}
\hline \multicolumn{2}{c|}{ Theme 1: Happy land (ceremonial wear) } & \multicolumn{2}{c}{ Theme 2: Peace of mind (everyday wear) } \\
\hline Design 1 & Design 2 & Design 3 \\
\hline
\end{tabular}

모양을 기반으로 하여 코바늘로 니트 장식을 더하였 다. 조끼는 본 작품의 포인트로 거친 마직물을 주로 이용하였다.

작품 3은 짧은 상의와 긴 주름 스커트로 디자인하 였다. 장족 여성들의 복식은 치마와 바지를 착용하면 서 허리띠와 앞치마를 함께 착용하는 특징이 있다. 상의 소매와 바지 부리에는 문양으로 장식된 단과 여 러 색의 굵기가 다른 긴 천으로 장식하는데 넓은 천 에는 아름다운 문양이 수놓아져 있다. 여성 명절 복 식은 상의길이는 다소 짧은 형태이고 팔의 길이는 손 목까지 오는 형태로 디자인을 전개하였다. 좡족 여성 들의 부지런히 일상에서 영감을 얻었으며, 단순한 파 랑색과 흰색을 주색으로 선정하여 자연풍경 무늬를 직조해서 조화시켰다. 좡족의 복식에 나타난 파랑색 을 주색으로 선정하여 데님소재를 바탕으로 패치워 크 기법과 니팅, 위빙 기법을 활용하였다.

작품 4는 좡족 일상생활에 많이 착용하는 긴 셔츠 에 착안하여 파랑색과 흰색을 활용하여 위빙 기법과 필팅 기법을 활용하여 디자인하였다. 무릎까지 내려 는 긴 셔츠의 특징을 과장된 느낌으로 길이를 발목까 지 늘려 디자인하였다. 전체적인 작품의 특징은 직선 적인 실루엣의 형태로 8 부 길이의 넓은 소매통과 독 특한 몸판과 앞치마를 표현하였다. 좡족의 자연숭배 사상과 소박한 생활 특징을 동시에 표현하고자 하였
으며, 평화로운 마음과 행복한 생활 모습을 보여주고 자 하였다. 펠트 기법과 위빙 기법을 사용하여 좡족 전통 텍스타일 문양을 제작하였으며, 주변 환경과 일 상생활에서 쉽게 볼 수 있는 동식물과 산, 강, 나무, 태양과 달 등 자연환경으로부터 영감을 얻은 문양을 응용하여 몸판과 앞치마에 자연과 물고기의 이미지 를 디자인하여 평화로운 자연 환경을 묘사하고자 하 였다(Table 2, Table 3).

\section{N. Conclusion}

중국은 한족과 55 개 소수민족으로 이루어진 다민 족 국가로 각각의 소수민족들은 다양하고 차별화된 복식 문화를 가지고 있다. 그러나 최근 현대화가 진 행되면서 소중한 자산인 전통복식에 대한 착용이 감 소하고 있는 추세이다. 중국이 글로벌화되면서 중국 의 전통 복식에 대한 관심이 높아지며 세계 복식 트 렌드에도 영향을 미치고 소수민족 복식에 관한 연구 도 증가하고 있지만, 일부에 불과하고 다양한 연구와 시도가 이루어지는 것은 아니다. 이에 본 연구는 중 국과 베트남에 걸쳐 거주하고 있는 민족으로 중국의 소수민족 중에서 인구가 가장 많음에도 아직 연구가 미흡한 좡족(壮族) 복식에 대하여 조사, 분석하고 소 수민족 복식의 현대화를 위한 패션디자인을 전개, 제 
<Table 2> Design development: Theme 1

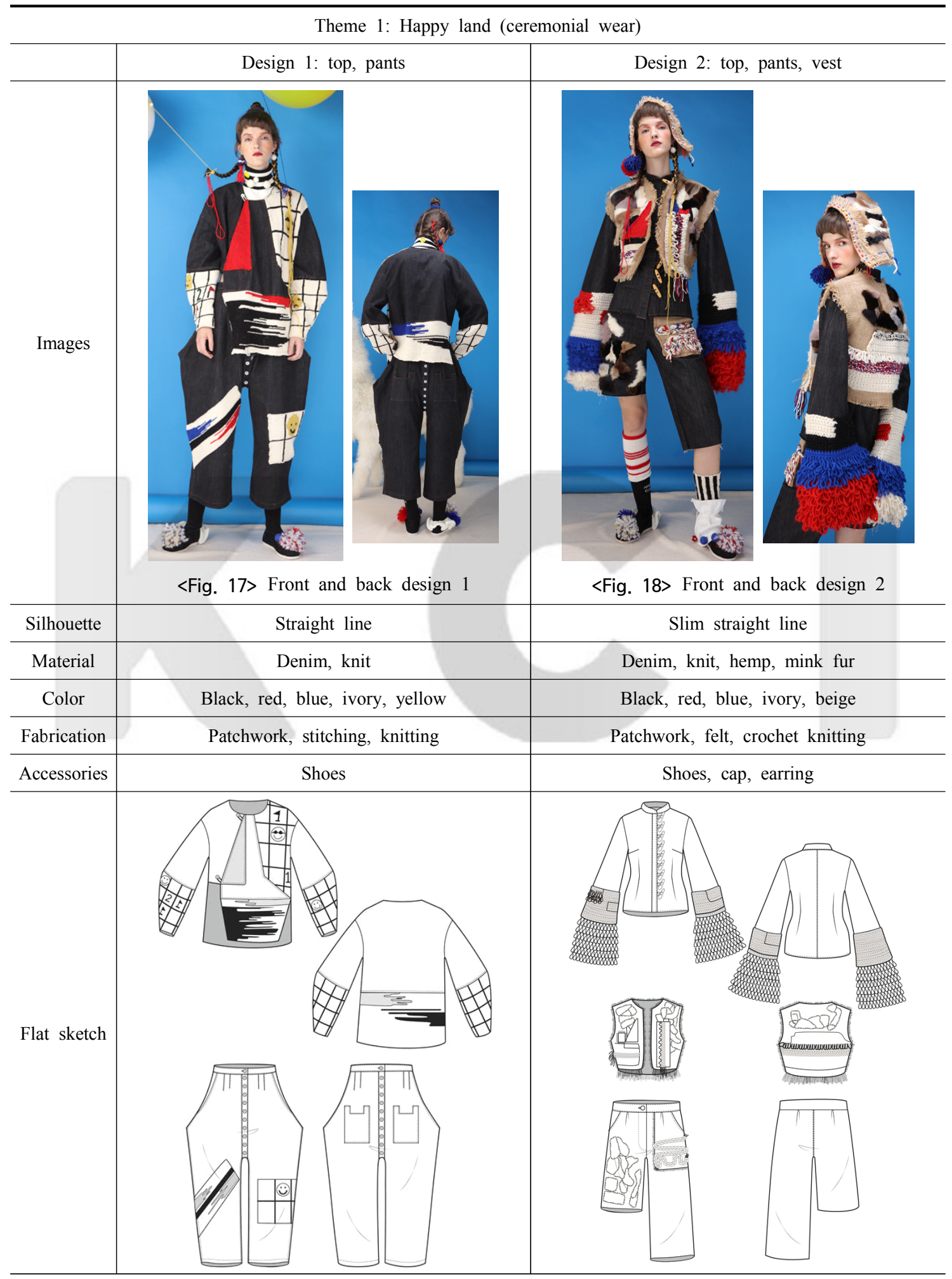


<Table 3> Design development: Theme 2

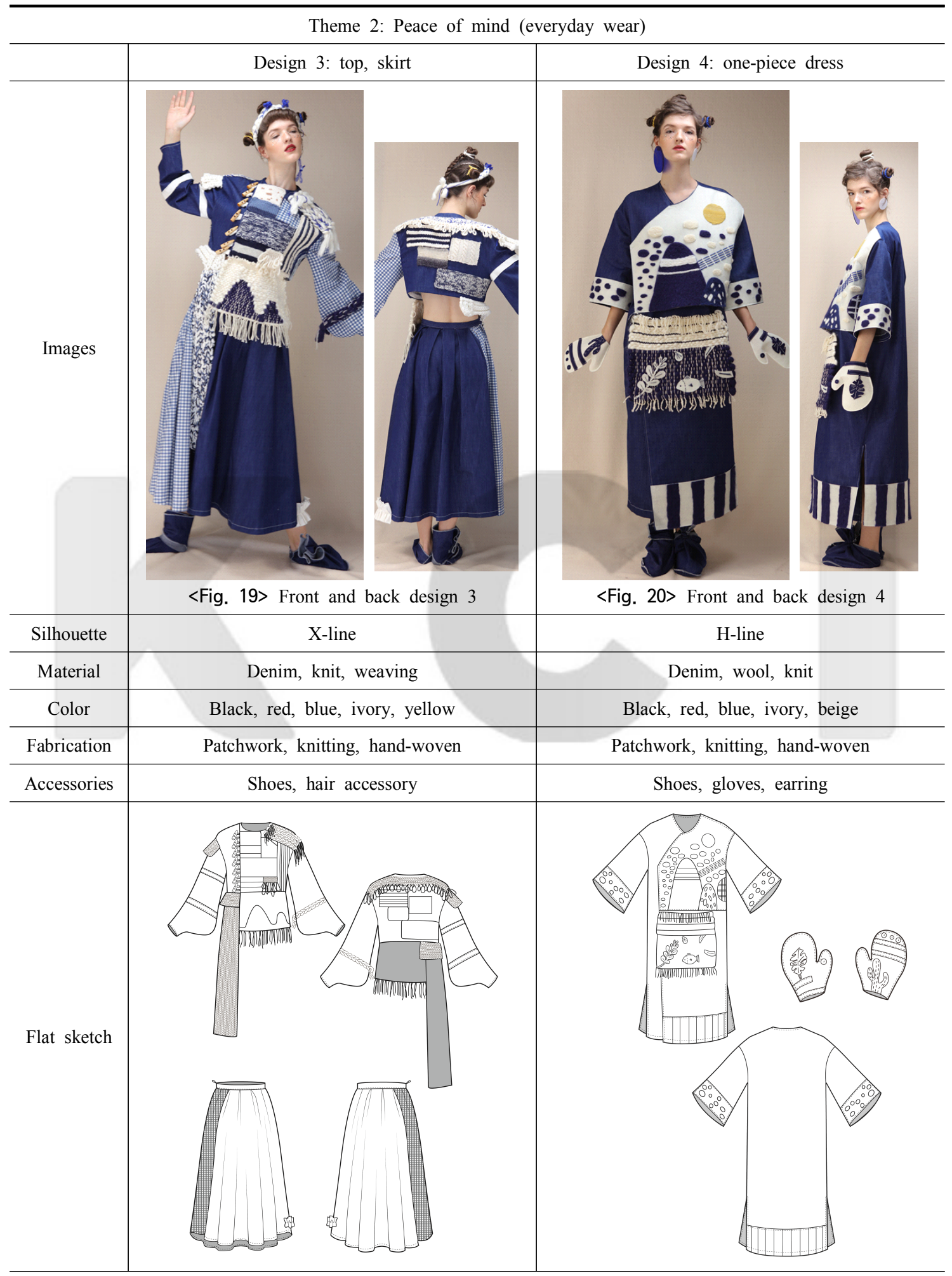


작하였다. 연구 방법으로 문헌고찰 및 선행연구를 바 탕으로 좡족의 문화적 배경을 고찰하고, 좡족 복식의 분석을 토대로 좡족 복식의 특성을 도출하였다. 이러 한 분석을 바탕으로 좡족 복식의 표현기법과 좡족 복 식의 모티브를 활용한 여성 패션디자인 4 벌을 제작하 였다.

본 연구의 결과는 다음과 같다. 첫째, 좡족 복식은 정교롭고 아름다우며 문화적으로 좡족의 정신세계를 표현하고 있다. 좡족 복식은 좡족의 인생과 생활의 산 물로 복식에는 좡족의 부지런함과 노력하는 생활태도, 소박한 마음을 잘 표현하고 있으며, 다양하면서 아름 답다. 둘째, 날염, 방직, 자수 등 섬세한 복식 표현기 법을 활용한다. 세 가지 기법을 활용해서 좡족 복식 의 우아하고 아름다운 모습을 잘 표현하였으며, 이는 중국 소수민족 복식 제작에서 매우 중요한 부분임을 알 수 있었다. 셋째, 이러한 좡족 복식의 특성과 표현 기법을 반영하여 두 가지 테마로 나누어 여성복 디자 인을 전개하고 제작하였다. 'Happy Land' 테마에서는 좡족 복식의 예복(艺服)를 기반으로 명절에 좡족 사 람들이 즐겁고 유쾌한 마음을 표현하였다. 색채는 좡 족사람들이 즐겨 착용하는 검정과 파랑을 주로 사용 하였다. 데님소재를 사용하였는데, 좡족 복식의 현대적 활용에 잘 맞는 소재임을 확인할 수 있었다. 니팅 기 법 및 모피, 마 원단을 패치워크, 니팅, 자수 등을 활 용하였다. 화려한 색상과 과장된 실루엣, 다양한 장식 물로 명절을 맞이하는 좡족 사람들의 기쁘고 행복한 마음을 표현하였다. 두 번째 테마인 'Peace of Mind' 의 작품 2 벌은 좡족 사람들이 평소에 자주 입는 편한 복식을 기반으로 좡족 사람들이 소박하고 부지런히 노력하는 모습을 보여주고자 하였다. 파랑색과 흰색 으로 좡족 사람들의 소박한 마음을 표현하였다. 태양, 산, 강, 풀, 물고기 등의 평화로운 자연 풍경을 무늬로 활용하여, 좡족의 자연숭배의 마음을 현대적 디자인 으로 전개하였다.

본 연구는 독특한 좡족 문화에 대한 분석을 통해 좡 족 복식의 특성을 파악하고, 전통복식에서 벗어나지 않고 현대패션의 중요한 위치에 있는 데님소재를 추 가하면서 새로운 패션디자인을 개발하였으며, 이를 계 기로 현대 패션 디자인에 대한 새로운 시각을 통한 다양한 디자인 개발의 가능성을 보여주었다. 또한, 중 국 소수민족 좡족의 복식과 시누아즈리(Chinoiserie)
라는 중국풍을 보여주고, 중국 전통복식의 많은 아이 디어가 현대 패션에도 좋은 사례가 될 수 있다는 것 을 확인할 수 있었다.

\section{References}

Beijing Institute of Fashion Technology. (n.d.a). Biftmuseum, Retrieved August 2, 2017, from http:// www.biftmuseum.com

Beijing Institute of Fashion Technology. (n.d.b). 云南 西畴壮族黑色刺绣女衣. Biftmuseum, Retrieved August 2, 2017, from http://www.biftmuseum.com/ collection $/$ info $?$ sid $=613 \&$ colCatSid $=2 \#$ atHere

Black costume of Zhuang. (2015, November 12). In 百度文库 [In Baidu library]. Retrieved August 5, 2017, from http://www.baike.com/wiki/\%E9\%BB $\% 91 \%$ E8\%A1\%A3\%E5\%A3\%AE

China.com. (2006, December 27). 大理白族扎染板蓝根 为原料 [Dali Bai Taizhi Banlang root as raw materials]. Retrieved August 7, 2017, from http:// www.china.com.cn/city/txt/2006-12/27/content 75 68219.htm

Costume of Zhuang. (2014, May 3). In 百度文库 [In Baidu library]. Retrieved August 5, 2017, from http:// www.baike.com/wiki/\%E5\%A3\%AE\%E6\%97\%8 F\%E6\%9C\%8D\%E9\%A5\%B0

Guangxi Zhuang Autonomous Region Museum. (n.d.). Gxmuseum, Retrieved August 2, 2017, from http:// www.gxmuseum.cn

Hwangmaehee. (2010), 중국행정구획총람 [Chinese administrative district overview]. Seoul: Author.

Lee, H. J. (2011, June 1). 中, 56개 민족의 용광로?‥ 갈등 뿌리깊은 화약고!. [China, 56 nation's furnace? $\cdots$ Conflict deeply rooted powder magazine!]. DongA.com, Retrieved August 5, 2017, from http:// news.donga.com/3/all/20110531/37685570/1http:// news.donga.com/3/all/20110531/37685570/1

Li, Q. S. (2014). Study of clothing design by utilizing the tibetan nationality's custume in China. Unpublished master's thesis, Honam University, Gwangju, Korea. 
Li, Y. J. (2012). 美丽的锦绣: 壮族服饰 [Beautiful Brocade Zhuang's Clothing]. Beijing: JIeli Publishing House.

Liu, Q., \& Kim, S. D. (2016). A study on characteristics and techniques of traditional textiles in Chinese ethnic minority. The Journal of the Korean Society of Knit Design, 14(2), 1-10.

National Bureau of Statistics of China. (2004). China's Ethnic Statistical Yearbook 2004. Beijing: Publishing House of Minority Nationalities.

Sammirabbit. (2010, August 10). 国内六大幽静避暑新 去处. [Six fresh and fresh places in the country]. Rayli network, Retrieved August 8, 2017, from http:/www.rayli.com.cn/lifestyle/0018/2010-08-09/ L0018010_753580_1.html

Seo, B. H. (2015). Study on modernization of the costumes of the ethnic minority in Yunnan, China. Korean Society of Fashion Design, 10(2), 19-31.

Textile printing. (n.d.) In Doopedia. Retrieved October 15, 2016, from http://www.doopedia.co.kr/doopedia/ master/master.do?_method=view\&MAS_IDX $=10$ 1013000734108

Wu, Z. \& Lee, H.-J. (2006). Characteristics of national races' costumes in Chinese contemporary costumes.
The Research Journal of the Costume Culture, 14(6), 956-970.

Xie, S. S. (2013). A comparative study between Tu jia costume and Miao costume in China. Unpublished master's thesis, Konkuk University, Seoul, Korea.

Yang, Y. (2005). 中国针织服饰全集 [China Knitwear Complete Works]. Tianjin: Tianjin Inmin misul chulpansa.

Yu, Y. Y.(2012, August 5). 彩裳绚烂山水牵: 美丽的 壮族服饰 [Colorful gorgeous landscape pull: Beautiful Zhuang costumes]. Guangmimg Daily, Retrieved August 5, 2017, from http://epaper.gmw.cn/gmrb/ html/2012-08/05/nw.D110000gmrb_20120805_111.htm

Zhang, Y. \& Kim, S.-J. (2011). Fashion design studies on reinterpretation of Chinese ethnic minority costumes. Journal of the Korean Fashion \& Costume Design Association, 13(2), 175-183.

Zhangiiajie. (2014, March 28). View on Zhangjiajie Miao costumes. Zhangjiajie Local Tour, Retrieved August 7, 2017, from http://www.zhangjiajietourism.com/ index.php? $\mathrm{m}=$ content $\& \mathrm{c}=$ index $\& \mathrm{a}=$ show $\&$ catid $=1$ $1 \& \mathrm{id}=62$ 